Research Article

\title{
Effects of Fire Frequency on Woody Plant Composition and Functional Traits in a Wet Savanna Ecosystem
}

\author{
Peter Makumbe $\mathbb{D}^{1},{ }^{1}$ Gift Chikorowondo, ${ }^{1}$ Pride Canisia Dzamara, ${ }^{1}$ Henry Ndaimani, ${ }^{2}$ \\ and Edson Gandiwa ${ }^{3}$ \\ ${ }^{1}$ Department of Natural Resources, Bindura University of Science Education, Private Bag 1020, Bindura, Zimbabwe \\ ${ }^{2}$ GIS and Earth Observation Centre of Excellence, Department of Geography, University of Zimbabwe, P.O. Box MP167, \\ Mt Pleasant, Harare, Zimbabwe \\ ${ }^{3}$ School of Wildife, Ecology and Conservation, Chinhoyi University of Technology, Private Bag 7724, Chinhoyi, Zimbabwe
}

Correspondence should be addressed to Peter Makumbe; pmakumbe7@gmail.com

Received 4 February 2020; Revised 19 October 2020; Accepted 21 October 2020; Published 3 November 2020

Academic Editor: Daniel I. Rubenstein

Copyright (c) 2020 Peter Makumbe et al. This is an open access article distributed under the Creative Commons Attribution License, which permits unrestricted use, distribution, and reproduction in any medium, provided the original work is properly cited.

\begin{abstract}
The objective of this study was to assess the effect of fire frequency on vegetation taxonomic and functional diversity in a wet savanna ecosystem, eastern Zimbabwe. The study area was stratified into three fire frequency regimes using a 15-year fire history (2000-2014) across the landscape: high (HFF: burnt every 1-2 years), medium (MFF: burnt every 3-4 years), and low (LFF: burnt every 5-6 years). Data were collected from a total of 30 plots measuring $20 \mathrm{~m} \times 20 \mathrm{~m}$ each between March and May 2018. In each plot, we recorded tree maximum height $\left(H_{\max }\right)$, woody plant density, basal diameter, resprouting capacity, and bark thickness. We calculated species evenness, diversity, functional richness (FRic), Rao's Quadratic Entropy (RaoQ), functional redundancy, and relative bark thickness. We recorded 1,031 individual trees belonging to 24 species across the three fire regimes. Significant differences across the three fire regimes were recorded for $H_{\max }$, woody plant density, and relative bark thickness $(P<0.05)$. $H_{\max }$ and woody plant density were higher in LFF than HFF regimes while relative bark thickness was higher in HFF than in the LFF regimes. Species evenness was significantly higher in HFF and MFF regimes than LFF regime $(P<0.05)$, while FRic and functional redundancy significantly increased with decreasing fire frequency $(P<0.05)$. However, no significant differences were recorded for resprouting capacity, species richness, taxonomic diversity, and RaoQ $(P>0.05)$. Species like Cassia petersiana, Cussonia spicata, Vachellia spp., and Rhus lancea were associated with LFF, while species like Protea gaguedi, Brachystegia utilis, and Vangueria infausta showed a strong association with HFF to MFF. Our study demonstrated that a combination of taxonomic and functional diversity metrics is adequate to evaluate the response of savanna vegetation to fire. We recommend a further assessment on vegetation composition using other elements of fire regimes.
\end{abstract}

\section{Introduction}

Fire is a global phenomenon which influences vegetation structure and composition with implications on ecosystem functioning [23]. In savannas, fire and herbivory are important determinants which facilitate the codominance of trees and grasses $[1,25,54]$, although fire is recognized as the principal modifier of structure, function, and dynamics of the savanna biome $[5,6,41]$. Different fire regimes can change vegetation structure and diversity
$[4,56]$ which may lead to decline in forest habitats and forest loss.

Fire is an important environmental filter in both wet and dry savanna woodlands $[10,11,52]$. The influence of fire on plant structure, composition, and functional traits depends on the nature of the fire regime that include frequency, intensity, type, and season $[19,26]$. Within the Zimbabwe savanna, the fire is seasonal starting around June when vegetation dries up and peaks in October (the driest month). In the eastern highlands of Zimbabwe, where this study was 
based, records from 1990 to 2015 show that fire has a 3- to 5year return interval although areas with good fire prevention mechanisms such as fireguards often escape the fire. Studies show that fire frequency affects vegetation both when the frequency is too high or too low and tends to eliminate the more sensitive species and thus favour the more resistant ones [14, 21]. For example, in their study in Zimbabwean south eastern Lowveld, Gandiwa and Kativu [21] found that high fire frequency (return interval of one to two years) altered vegetation structure of Colophospermum mopane and Combretum apiculatum species. Similarly, Devine et al. [16] reported that increased fire frequency (annual return interval) resulted in greater proportion of multistemmed trees in a wet savanna. Although fire has a strong influence on savanna woodland dynamics and function [52], the relationship between fire frequency and these ecosystem properties is still poorly understood in most of the wet savanna ecosystems. In wet savannas, fires tend to limit the productivity of woody species more than in dry savannas where cover is instead inhibited by water availability $[8,16]$. This is important because depending on fire frequency species with specific traits such as bark thickness [31, 43], epicormic resprouting [25], and rapid growth tend to escape the fire zone thus becoming more tolerant to frequent fires. Bark thickness, in particular, positively correlates with fire frequency suggesting protection function on tree stem mortality [31, 58]. Bark thickness confers individual fire resistance with those trees with thick bark regardless of stem width or height surviving severe fires [43]. Thick bark allows for the protection of vascular cambium and the buds in the lateral meristem from fire [30] thus allowing tree resprouting after fire.

The impacts of fire on the biodiversity response of savanna woody species have been extensively carried out using taxonomic measures of diversity such as species richness and Shannon indices of diversity with little consideration of plant traits, ecological niches, and life history patterns $[43,52]$. Yet, environmental disturbance such as fire can act as an environmental filter that causes some traits to persist under certain conditions $[9,14]$. Thus, using only traditional diversity measures may provide inadequate information as indicators of changes in community structure and dynamics, underestimating the true extent of biodiversity loss following disturbance $[9,36]$. This is because taxonomic diversity alone (e.g., species diversity) is a poor surrogate of ecosystem functioning [39]. According to Díaz and Cabido [17], diversity encompasses both number and composition of species and functional types; yet many studies only equate diversity to species richness with little consideration of functional diversity.

One solution that has been proposed to bridge the gap between species richness and their role in the community is measuring both taxonomic and functional diversity [36] as their results may complement each other. Functional diversity measures seek to quantify the range of functional trait space among species in a community $[36,47]$, thus providing information on ecosystem processes which takes into account plant life history. Studies highlight that trait-based approaches provide insights into processes by which environmental changes affect biological communities and thus help predict future changes $[40,50]$. In cases where environmental disturbances such as fire disproportionately affect species with shared traits, niche processes become the driving force behind community changes and leads to loss in functional diversity [35]. An important aspect of ecosystem change is resilience which is the capacity of a community to return to its initial state after a perturbation [33]. Resilience can be evaluated indirectly by assessing functional redundancy or the presence of different species in a community showing the same effects on an ecosystem process but different response to the disturbing factor $[17,18]$. Resilience measures the risk of losing ecosystem functions resulting from the loss of all species from a functional group [42] making evaluation of this risk through functional redundancy important. Thus, ecosystem processes and functioning can be better evaluated by incorporating both taxonomic and functional diversity in studies as the two tend to complement each other [44].

To date, there are limited studies focusing on the phenomena of functional diversity on savanna woody species following a fire disturbance, which limits our understanding of the effects of fire on ecosystem functioning and trait-based response of woody plants to fire frequency [52]. In addition, savannas experiencing over $650 \mathrm{~mm}$ as is the case with the present study site, Nyanga National Park (NNP), eastern Zimbabwe, are relatively unstable compared to drier savannas [53]. Therefore, studying their resilience in the face of perturbation is crucial.

Here, we assessed the effect of fire frequency on taxonomic and functional diversity of wet savanna woody species in NNP using a 15-year fire history (2000-2014) across the landscape; high fire frequency (HFF: burnt every 1-2 years), medium fire frequency (MFF: burnt every 3-4 years), and low fire frequency (LFF: burnt every 5-6 years). We hypothesised that woody plants in HFF zones would have relatively thicker bark and higher resprouting capacity compared to MFF and LFF zones. Due to top kill, we predict that woody plants in HFF zones would invest in stem growth instead of height; thus shorter plants are expected in HFF compared to LFF. Taxonomic diversity, species richness, and woody plant density are predicted to be higher in LFF zones compared to the MFF and HFF zones. We expected that fire frequency could act as an environmental filter of plant traits studied here resulting in lower values of functional diversity and redundancy measures in HFF zones.

\section{Materials and Methods}

2.1. Study Area. The study was carried out in NNP in the eastern highlands of Zimbabwe (Figure 1). The park covers an area of $471 \mathrm{~km}^{2}$ and is characterized by a cool and wet climate with mean annual rainfall of $1,200 \mathrm{~mm}$. Average annual temperatures range from a minimum of $9-12^{\circ} \mathrm{C}$ to a maximum of $25-28^{\circ} \mathrm{C}$. The rainfall period stretches from October to April. NNP contains the largest undisturbed area of montane grasslands in Zimbabwe with a large proportion of the Afro-montane forests, particularly on Nyangani Mountain. The high humidity and low evaporation rates provide good conditions for continuous plant growth 


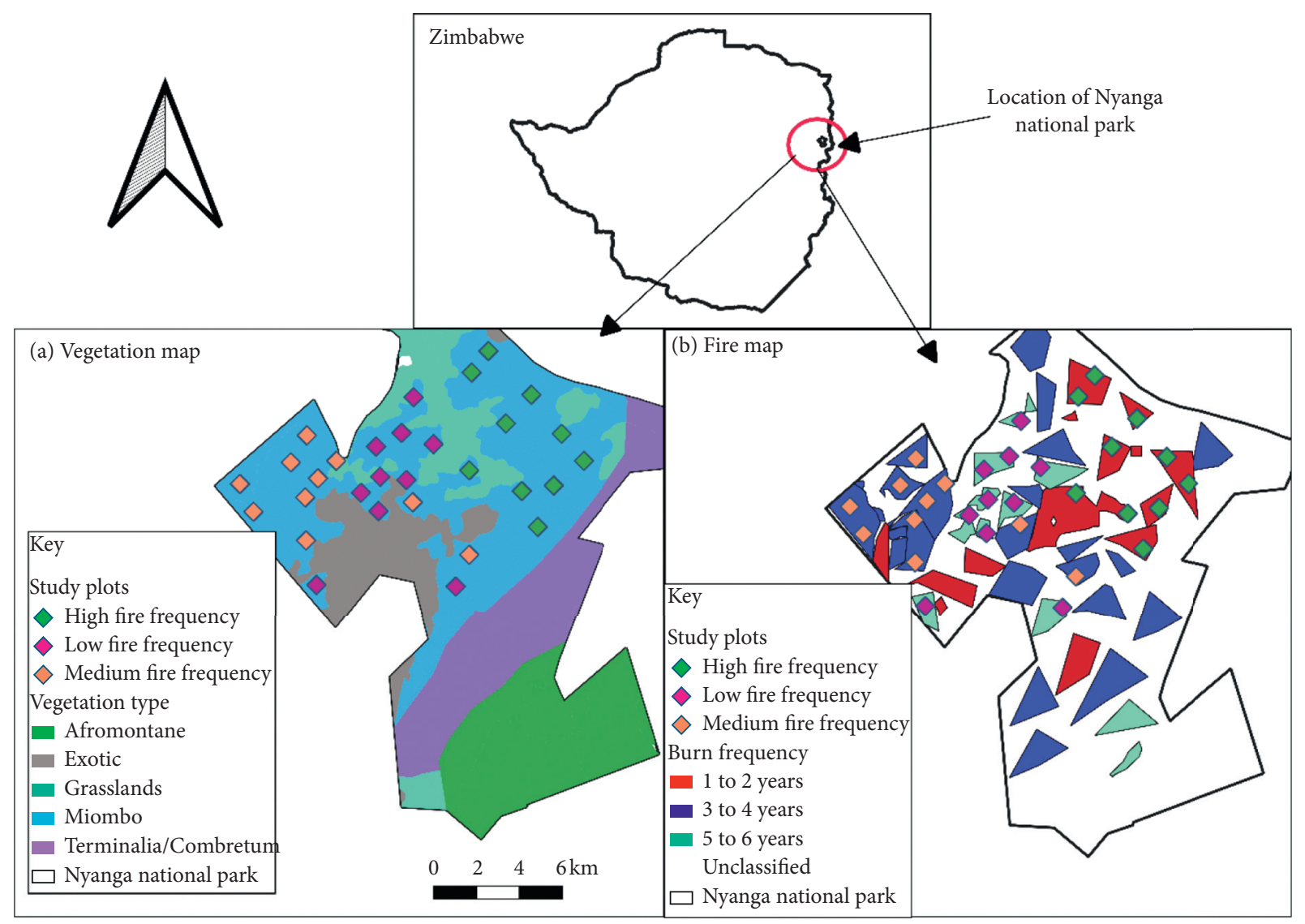

Figure 1: Fire and vegetation map for Nyanga National Park, eastern Zimbabwe.

throughout the year [20]. The park has fynbos-like vegetation on the plateau summit, miombo woodland, and moist Afro-montane forest on the low altitude forming part of the unique ecoregion which stretches from the Cape Province in South Africa to the Ethiopian highlands.

Historical data based on the period 1990 to 2015 shows that the fire return interval in NNP ranges between 3 and 5 years although areas with good fireguards can go up to 10 years without fire. Extensive grass fires occurring in the high-elevation grasslands from August to November are causing extensive loss of biodiversity [64]. Although the biodiversity in this grassland has developed in association with fire, there has been an increase in fire frequency in recent years caused by poachers and the villagers surrounding NNP. As a result, grass in this area has not had enough time to regenerate causing a cascading loss in herbivores.

2.2. Experimental Design. The study was based on stratified random sampling method on three different fire frequencies which are high fire frequency (HFF), medium fire frequency (MFF), and low fire frequency (LFF). The classification was based on the number of years each area was burnt: every 1 to 2 years (HFF), every 3 to 4 years (MFF), and every 5 to 6 years (LFF) following Kativu and Nyazika et al. [21, 45]. The data was based on a 15-year fire history covering the period 2000 to 2014. Fire history data were obtained from records kept at NNP. We used data from both prescribed and wildfires. Most fires (about 60\%) recorded in NNP are wildfires and anthropogenically induced while the remaining $40 \%$ of the fires are controlled burns used as a management tool and to control invasive species [15].

Geographical aspects such as rainfall, soil, aspect, slope, and other terrain features can affect vegetation distribution and fire regimes thus shaping savanna ecosystems $[6,55]$. To control for these confounding variables, we overlaid the generated fire map onto a generalised vegetation and soil map of NNP to sample areas with approximately the same vegetation and soil type. Then using a digital elevation model, we calculated the aspect and the slope of the park. We then overlaid the resultant map on top of the fire frequency map to sample areas with the same aspect and same gradient. Lastly, using ARCGIS software, we randomly generated points within each patch that satisfied any of the three fire regimes (HFF, MFF, and LFF) as well as having similar vegetation type, soil, aspect, and slope.

2.3. Data Collection. Thirty plots (ten per each fire regime) were sampled for vegetation for a period of three months from March-May 2018 (Figure 1). Each plot measured $20 \mathrm{~m} \times 20 \mathrm{~m}$ translating to 0.04 ha. In each plot, all woody plants (trees and shrubs) were counted and identified to species level with the assistance of a botanist and a guidebook by [12]. Trees were defined as rooted, woody, self- 
supporting plants $\geq 3 \mathrm{~m}$ high and/or with a basal stem diameter $\geq 6 \mathrm{~cm}$, whereas shrubs were defined as rooted, selfsupporting $<3 \mathrm{~m}$ high, and $<6 \mathrm{~cm}$ in stem basal diameter [3]. All woody plants rooted within the plot were recorded and measured. Woody plants occurring along plot margins were included if at least half of the rooted system was inside the plot [62]. To determine woody plant density (stems/ha), the following formula was used:

$$
\text { woody plant density }\left(\frac{\text { stems }}{\mathrm{ha}}\right)=\frac{\text { number of plants } \times 10000 \mathrm{~m}^{2}}{\text { plot area }\left(\mathrm{m}^{2}\right)} \text {. }
$$

All trees were sampled for growth traits using the following methods. We measured the maximum height $\left(H_{\max }\right)$ of trees by placing a calibrated $6 \mathrm{~m}$ pole against it. $H_{\max }$ is the maximum stature a mature individual of a species attains in a given habitat [46]. For trees $>6 \mathrm{~m}$, the pole was manually uplifted or height visually estimated by observing it at a distance away from the tree. On multistemmed plants, only the height of the tallest stem was considered. The basal diameter of each stem was measured just above the buttress swelling (to the nearest centimetre) using a flexible $5 \mathrm{~m}$ diameter tape.

Bark thickness (to the nearest $0.1 \mathrm{~mm}$ ) was measured on 10 healthy trees that were randomly selected in each plot [46]. On each tree, bark thickness was measured using a bark gauge (Suunto, Finland) near the base at $40 \mathrm{~cm}$ height, the region where most surface fires occur. Because bark thickness is correlated with stem diameter, changing rapidly with taper [22], we calculated the relative bark thickness instead of using absolute bark thickness and basal diameter separately:

relative bark thickness $\left(\frac{\mathrm{mm}}{\mathrm{cm}}\right)=\frac{\text { bark thickness }(\mathrm{mm})}{\text { stem diameter }(\mathrm{cm})}$.

Resprouting capacity (0-100, unitless) was recorded based on tree capacity to form new shoots after destruction of most of its above ground biomass using reserves from basal or below ground plant parts following the procedure in Pérez-Harguindeguy et al. [46]. We estimated the average percentage of above ground biomass destroyed (percentage destroyed) and percentage of damaged plant population that has resprouted (percentage resprouters) for a sample of 10 similar species from each fire regime and calculated resprouting capacity as follows:

$$
\text { resprouting capacity }=\frac{\text { percentage destroyed } \times \text { percentage resprouters }}{100} .
$$

\section{Data Analyses}

3.1. Community Composition. Changes in community structure were assessed using community metrics [13]. Richness was measured as the number of different vegetation types of species present. Species diversity was measured using Shannon-Wiener diversity index $\left(H^{\prime}\right)$ while equity was measured using Pielou's evenness $(J)$. The metrics were calculated for the three fire frequencies using relative frequencies of the identified woody plants in statistical package ESTIMATE S [13]. We then conducted a generalised linear model (GLM) with Poisson distribution for the effects of fire on tree $H_{\text {max }}$, woody plant density, and relative bark thickness. Community metrics (richness, diversity, and evenness) were compared for differences among the fire frequencies using a GLM with negative binomial distribution. When differences occurred, a Tukey's Honest Significant Difference (HSD) post hoc test was used to determine differences among the fire frequencies. The GLM was performed using the "nlme" package [48] in the statistical package $R$ version 3.5.1 [51] with significant levels set at $P<0.05$.

We conducted a Canonical Correspondence Analysis (CCA) in CANOCO version 4.5 for Windows [59] to identify the spatial ordination of damage by fire using plots as the spatial factor. The resultant triplot was based on the significant first and second axes.

3.2. Functional Diversity and Redundancy. To calculate functional diversity metrics, we used the trait data from Table 1. In addition to maximum height, relative bark thickness, and resprouting capacity, we included three categorical variables: fire response group, ecological group, and capacity to fix nitrogen. Fire response group was classified into five categories following [32] groups. For ecological group, woody plants were classified as evergreen, deciduous, or semideciduous if they bear their foliage throughout the year, shed their foliage during the dry season, or only shed their foliage for a very short time in late winter and rejuvenating quickly, respectively. Lastly, woody plants were classified as having the capacity to host nitrogen fixing bacteria (nitrogen fixers) or not. Then, using species relative abundances, we calculated two complimentary multidimensional measures of functional diversity: (1) functional richness (FRic), which quantifies the volume of functional space that a set of species occupies [60], and (2) Rao's 
TABLE 1: List of functional traits derived from measurements in savanna woodlands of Nyanga National Park and from the literature.

\begin{tabular}{lcc}
\hline Trait & Variable & Source \\
\hline Maximum height $\left(H_{\max }\right)$ & Continuous $(\mathrm{m})$ & Measurement \\
Relative bark thickness & Continuous $(\mathrm{mm} / \mathrm{cm})$ & Measurement \\
Resprouting capacity & Continuous (index: 1-100) & Measurement \\
Fire response group & Categorical: Group 1-group 5 & [32]; literature \\
Ecological group & Categorical: Evergreen, deciduous, semideciduous & [12]; literature \\
Nitrogen fixation & Binary: Yes/no & {$[12] ;$ literature } \\
\hline
\end{tabular}

quadratic entropy (RaoQ), which measures functional diversity by incorporating both the relative abundances of species and a measure of the pairwise functional differences between species [7]. Since our functional traits were a mixture of continuous, binary, and discrete variables, we calculated a distance matrix using the Gower distance measure which allows individual traits to be weighted differently [49], before running a principal coordinates analysis (PCoA) in the FD package to calculate a new trait matrix of transformed coordinates [60]. The resultant PCoA axes were used to calculate the functional measures using a multidimensional convex hull to position species in functional trait space [63]. All functional diversity indices were calculated using the FD package [29] in $R$ statistical computing.

Functional redundancy was calculated based on Bello et al. [2] method which defines functional redundancy as the part of the species diversity in the community that has not been explained by functional diversity. As a result, functional redundancy (FR) is the difference between the functional diversity (FD) and the species diversity (SD) given by

$$
\mathrm{FR}=\mathrm{SD}-\mathrm{FD}
$$

where SD is represented by the Shannon-Wiener diversity $\left(H^{\prime}\right)$ index and FD is represented by RaoQ [7].

\section{Results}

4.1. Vegetation Composition and Structure. Across the three fire frequencies, we recorded 1,031 woody plants belonging to 24 species in 30 sampling plots (Table 2). Of these species, Acacia mearnsii and Pinus patula are exotic species. $H_{\max }$ was significantly different among the fire frequency plots $(P<0.05)$ with the tallest trees found in LFF regime and shortest trees in HFF regime. Relative bark thickness significantly increased with increasing fire frequency with thicker barks in HFF than MFF and LFF regimes $(P<0.05)$. Resprouting capacity did not differ across the three fire frequency regimes (Table 3 ).

Woody plant density was significantly different among the three fire frequency regimes $(P<0.05)$ with the highest species density of 542.44 stems/ha in LFF regime and the lowest of 476.92 stems/ha in MFF regime. Species evenness among the three fire frequency regimes were significantly different $(P<0.05)$, while diversity and richness were not significant $((P>0.05)$, Table 3$)$.
4.2. Community Multivariate Analysis. CCA 1 (eigenvalue $=0.46)$ explained $49.21 \%$ of variance, while CCA 2 (eigenvalue $=0.15$ ) explained $16.92 \%$ of variance in the taxa-environment relations (Figure 2). Both axes were significant (Monte Carlo test, $F=1.38 ; P=0.024$ ). The ordination separated plots in the LFF from those in the HFF. Species like Cassia petersiana, Cussonia spicata, Vachellia tortilis, V. amythethophylla, and Rhus lancea were associated with low frequency fire, while species like Protea gaguedi, Brachystegia utilis, Vangueria infausta, and Combretum spp. showed a strong association with HFF to MFF. Species such as A. mearnsii, Vangueria infausta, and Syzygium cordatum had higher richness in LFF plots. Species with higher sprouting capacity included Protea gaguedi, Combretum zeyheri, C. molle, and Cassia petersiana (Figure 2).

4.3. Tree Functional Diversity. FRic was significantly higher in LFF regime than in the other two regimes $(P<0.05)$, while RaoQ remained constant across the three fire frequency regimes. Functional redundancy significantly decreased from 1.52 in LFF regime to 1.26 in HFF regime $(P<0.05)$. From LFF sites to HFF sites, an average of $36 \%$ of functionally redundant species was lost. The functional space occupied by tree species in NNP showed constrictions, indicating a loss of some functional traits (Figure 3 ). In particular, the proportion of nitrogen fixers was $13 \%$ lower in HFF sites than in LFF sites.

\section{Discussion}

Fire is an important driver of vegetation structure and diversity in savanna ecosystems although extreme fire regimes threaten ecosystem functioning $[6,52]$. In this study, we explored the effects of fire frequency on savanna community composition and structure by quantifying both taxonomic and functional diversity of this community. Our results showed that maximum tree height decreased with increasing fire frequency. The decrease in tree height with increase in areas of high fire frequency may be attributed to plant tissue top kill on large trees [21] which prevents them from growing taller. When trees fail to escape the fire zone, they will be unable to gain enough height between fire disturbance regimes resulting in them being "trapped" in the fire zone for a long time [61]. This can explain why shorter trees were found in HFF. When trees fail to escape the fire zone, they then develop strategies to survive the intense fires. For 
TABle 2: Tree species (\% occurrence) across the three fire frequency strata in Nyanga National Park.

\begin{tabular}{|c|c|c|c|c|}
\hline Tree species & Family & HFF & MFF & LFF \\
\hline Acacia mearnsii & Fabaceae & 25 & 9 & 21 \\
\hline Brachystegia glaucescens & Fabaceae & 23 & 6 & 20 \\
\hline Brachystegia spiciformis & Fabaceae & 79 & 63 & 89 \\
\hline Brachystegia utilis & Fabaceae & 16 & 17 & 19 \\
\hline Burkea africana & Caesalpiniaceae & - & 26 & 30 \\
\hline Cassia petersiana & Caesalpiniaceae & 16 & - & 10 \\
\hline Combretum molle & Combretaceae & 30 & 15 & 29 \\
\hline Combretum zeyheri & Combretaceae & 10 & - & - \\
\hline Cussonia spicata & Araliaceae & 3 & 15 & 9 \\
\hline Dichrostachys cinerea & Fabaceae & 5 & - & - \\
\hline Diplorhynchus condylocarpon & Apocynaceae & - & 16 & - \\
\hline Julbernardia globiflora & Fabaceae & 45 & 45 & 37 \\
\hline Lannea discolor & Anacardiaceae & - & 16 & 7 \\
\hline Parinari curatellifolia & Chrysobalanaceae & - & 14 & - \\
\hline Pinus patula & Pinaceae & 4 & 9 & - \\
\hline Protea gaguedi & Proteaceae & 31 & 7 & 21 \\
\hline Prunus africana & Rosaceae & - & 8 & 11 \\
\hline Rhus lancea & Anacardiaceae & - & 21 & 6 \\
\hline Syzygium cordatum & Myrtaceae & - & 6 & 4 \\
\hline Syzygium guineense & Myrtaceae & - & - & 8 \\
\hline Vachellia amythethophylla & Fabaceae & - & 8 & 8 \\
\hline Vachellia karroo & Fabaceae & 15 & 4 & 16 \\
\hline Vachellia tortilis & Fabaceae & 20 & 14 & - \\
\hline Vangueria infausta & Rubiaceae & 18 & 11 & 16 \\
\hline
\end{tabular}

HFF: high fire frequency; MFF: medium fire frequency; LFF: low fire frequency, and not recorded.

TABLE 3: Stand structure, diversity metrics, and functional diversity indices measured in high fire frequency (HFF), medium fire frequency $(\mathrm{MFF})$, and low fire frequency (LFF) (mean \pm standard error).

\begin{tabular}{|c|c|c|c|c|c|}
\hline \multirow{2}{*}{ Metric/measurement } & \multicolumn{3}{|c|}{ Fire regime } & \multirow{2}{*}{$\mathrm{F}_{2,27}$} & \multirow{2}{*}{$P$} \\
\hline & HFF & MFF & LFF & & \\
\hline \multicolumn{6}{|l|}{ Stand structure } \\
\hline$H_{\max }(\mathrm{m})$ & $5.67 \pm 0.11^{\mathrm{a}}$ & $6.02 \pm 0.17^{\mathrm{a}, \mathrm{b}}$ & $8.22 \pm 0.19^{\mathrm{b}}$ & 22.49 & 0.0001 \\
\hline Woody plant density (species/ha) & $492.76 \pm 67.23^{\mathrm{a}, \mathrm{b}}$ & $476.92 \pm 23.22^{\mathrm{a}}$ & $542.44 \pm 74.89^{\mathrm{b}}$ & 16.72 & 0.004 \\
\hline Resprouting capacity & $48 \pm 4.26^{\mathrm{a}}$ & $52 \pm 5.73^{\mathrm{a}}$ & $53.07 \pm 3.28^{\mathrm{a}}$ & 1.69 & 0.41 \\
\hline Relative bark thickness $(\mathrm{mm} / \mathrm{cm})$ & $18.84 \pm 0.63^{\mathrm{a}}$ & $9.87 \pm 0.68^{\mathrm{b}}$ & $6.28 \pm 0.76^{\mathrm{c}}$ & 87.17 & 0.02 \\
\hline \multicolumn{6}{|l|}{ Tree diversity metrics } \\
\hline Species richness & $4.40 \pm 0.45^{\mathrm{a}}$ & $4.3 \pm 0.47^{\mathrm{a}}$ & $5.80 \pm 0.44^{\mathrm{a}}$ & 3.39 & 0.051 \\
\hline Shannon-Wiener $H^{\prime}$ & $1.31 \pm 0.15^{\mathrm{a}}$ & $1.32 \pm 0.11^{\mathrm{a}}$ & $1.57 \pm 0.08^{\mathrm{a}}$ & 1.55 & 0.232 \\
\hline Pielou's evenness $J$ & $0.92 \pm 0.02^{\mathrm{a}}$ & $0.92 \pm 0.01^{\mathrm{a}}$ & $0.76 \pm 0.02^{\mathrm{b}}$ & 4.34 & 0.023 \\
\hline \multicolumn{6}{|l|}{ Functional diversity } \\
\hline FRic & $1.1 \pm 0.001^{\mathrm{a}}$ & $0.09 \pm 0.03^{\mathrm{a}}$ & $0.15 \pm 0.03^{\mathrm{b}}$ & 7.24 & 0.003 \\
\hline RaoQ & $0.05 \pm 0.01^{\mathrm{a}}$ & $0.03 \pm 0.01^{\mathrm{a}}$ & $0.05 \pm 0.001^{\mathrm{a}}$ & 2.44 & 0.107 \\
\hline Functional redundancy & $1.26 \pm 0.15^{\mathrm{a}}$ & $1.28 \pm 0.11^{\mathrm{a}}$ & $1.52 \pm 0.08^{\mathrm{a}}$ & 4.62 & 0.021 \\
\hline
\end{tabular}

Means with different superscripts in the same row are significantly different (Tukey's HSD post hoc $(P<0.05)$ ).

example, after a burn, many trees invest energy into growing wider stem at the expense of height and often develop thicker bark to avoid top kill by fire [31]. Studies have demonstrated that relative bark thickness rather than absolute bark thickness is a better indicator of fire-tolerance or resistance in some species [27] better predicting their survival. In this study we used relative bark thickness rather than absolute bark thickness. Charles-Dominique et al. [11] found that high fire frequency was associated with thicker bark and high bark growth rate. This observation is consistent with our results as tree relative bark thickness was higher in HFF than LFF fire regime. Thick bark allows trees to minimize or escape fire damage by insulating meristems and bud primordia [46] especially vascular cambium and xylem tissue [31, 37]. Thus, the probability of survival of individuals with thicker bark is greater [31].

Our results demonstrated that woody plant density was lower in HFF than LFF regime. The decrease in woody density with an increase in fire return intervals corroborates well with other studies in the savanna ecosystem [45, 57]. Repeated fires, for example, biennial fires, can result in tree mortality regardless of the fire-tolerance abilities of the 


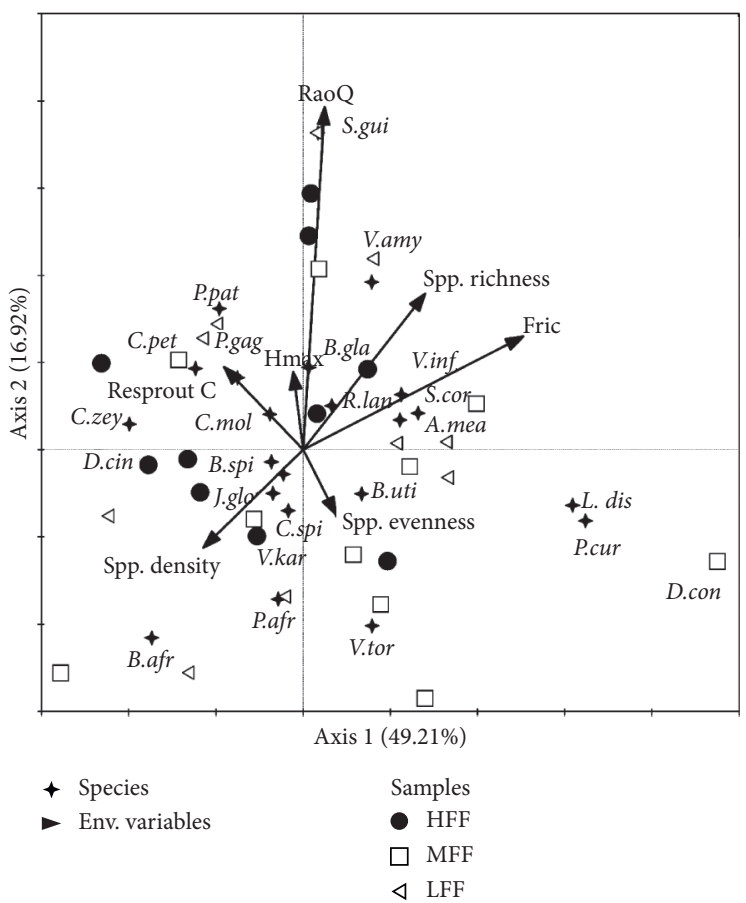

Figure 2: Triplot based on a CCA (first two axes explaining $66.13 \%$ of total variation) illustrating the location of the three fire frequency regimes (HFF), medium fire frequency $(\mathrm{MFF})$, and low fire frequency (LFF), environmental variables (Fric = functional richness; RaoQ = Rao's Quadratic Entropy; Resprout $C=$ resprouting capacity; Spp. = species) and tree species within multivariate space. Key to species: A. mea = Acacia mearnsii; B.gla = Brachystegia glaucescens; B.spi=Brachystegia spiciformis; $B$. uti $=$ Brachystegia utilis; B.afr $=$ Burkea africana; C.mol=Combretum mole; C.zey=Combretum zeyheri; C.pet=Cassia petersiana; D.cin=Dichrostachys cinerea; D.con = Diplorhynchus condylocarpon; J.glo = Julbernardia globiflora $;$ L.dis = Lannea discolor; P.cur $=$ Parinari curatellifolia $;$ P.pat $=$ Pinus patula; P.gag=Protea gaguedi; P.afr=Prunus africana; R.lan=Rhus lancea; S.cor=Syzygium cordatum; S.gui=Syzygium guineense; V.Amy = Vachellia amythethophylla; V.kar =Vachellia karroo; V.tor = Vachellia tortilis; V.infa=Vangueria infausta.

woody species because of limited recovery time [52]. Also, high fire frequencies can kill and prevent the establishment of saplings and seedlings from growing resulting in poor recruitment with time [3]. However, in other studies, woody plant density has been shown to increase with fire frequency as the woody vegetation build resilience to fire through their adaptive capacity to resprout from root stocks $[25,43,57]$ and multistemming from basal coppices [21]. Therefore, effects of fire frequency on density of woody species may vary with fire resilience of woody species, local site factors that influence vegetation productivity, and competitive interactions [57].

Lack of significant differences in species richness and diversity among the fire frequency zones suggest that fire frequency does not have a marked effect on woody species composition as also recorded in other studies (e.g., $[21,45])$. The response of woody species to fire is woodland and species specific [38]. Woody species response to fire is dependent on the species sensitivity, developmental and physiological state, and the duration and intensity of the fire [52]. However, higher evenness indices at HFF and MFF show that the homogeneity of distribution of abundances among species (evenness) was important in structuring the biological community compared to the diversity of woody tree species. While the Shannon-Wiener diversity indices are sensitive to both relative abundances and number of species, Pielou's evenness indices are sensitive to homogeneity of distribution of abundances among species [28]. Therefore, in this study, the homogeneity of distribution of species was more important in explaining differences among sites than the diversity of taxa.

Demographic characteristics related to the influence of fire are best explained by whether the species is fire-tolerant or fire-sensitive [38]. The ordination results showed that Julbernardia globiflora, Brachystegia spp., and Vangueria infausta were associated with high fire frequency. These results are consistent with previous findings which showed that miombo woody species are fire-tolerant species [10]. Fire tolerance was also shown by Protea gaguedi and Combretum zeyheri with a strong association with high frequency fires pointing to their anatomical and morphological adaptive strategies. For instance, Protea spp. have high epicormic resprouting potential stimulated by fire and Combretum spp. possess a thick bark [12] which reduces heat conductance [30].

It has been observed that taxonomic species richness is not always a surrogate of functional richness although there is often a positive relationship between them [17]. Functional richness (FRic) were significantly lower in HFF. This is further supported by the convex hull which showed constrictions in the niche space occupied by tree species in MFF and LFF zones. These findings indicate that where functional redundancy is low, increased fire frequency can result in 


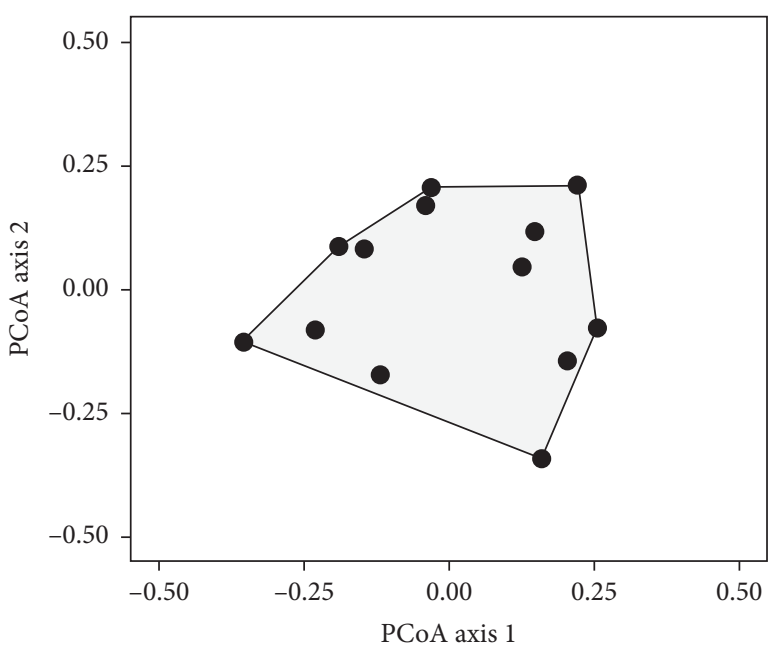

(a)

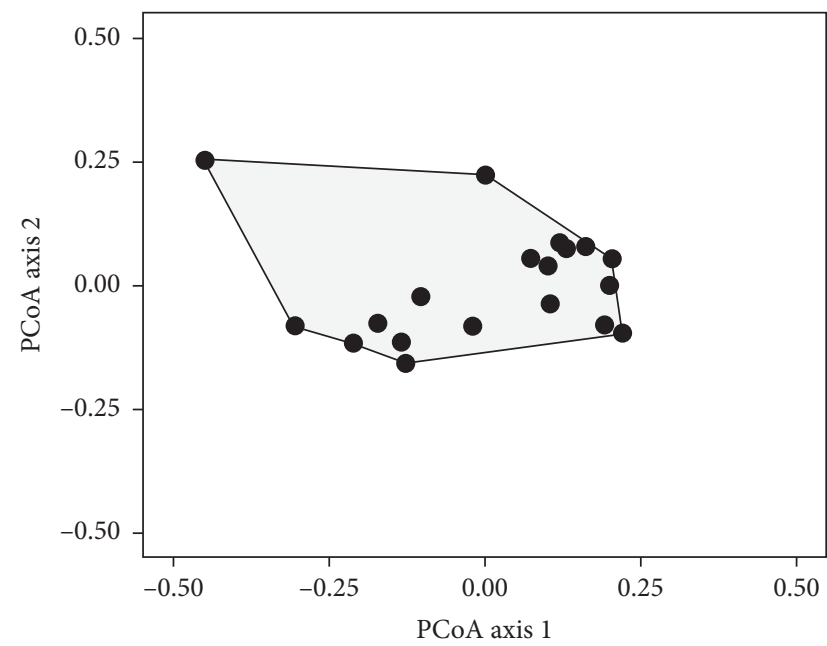

(b)

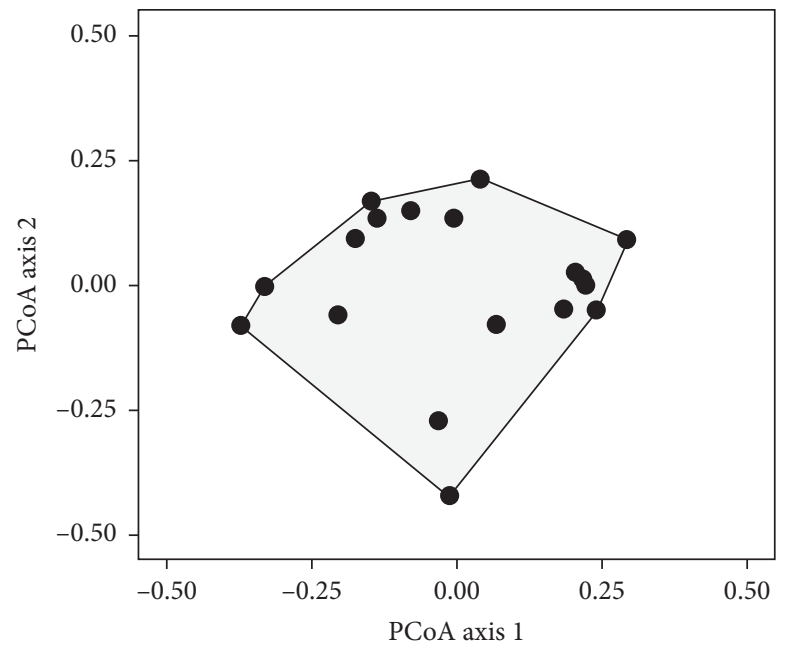

(c)

Figure 3: Functional richness of savanna tree community represented as the minimum convex hull enclosing all species in a community (denoted here by the area of the grey polygon), in (a) high fire frequency (HFF), (b) medium fire frequency (MFF), and (c) low fire frequency (LFF) [24].

losses of whole functional groups, and this can lead to ecosystem function disturbances.

Functional redundancy evaluates the risk of losing ecosystem functions resulting from the loss of all species from a functional group [42]. As a result, functional redundancy can be used to predict community resilience in the face of perturbations. In the present study, functional redundancy significantly decreased with increase in fire frequency. This implies that the risk of losing whole ecosystem functions can increase as fire frequency increases. For instance, an average of $36 \%$ of functionally redundant species were lost from HHF plots. Also, the proportion of nitrogen fixers was much lower (13\%) in high fire frequency zones than LFF plots (50\%) which suggest that such functions will be lost and the probability of survival of fire-intolerant species is reduced as fire frequency increases [52]. The loss of nitrogen fixers means further perturbations can lead to further losses with a consequence on other species that depend on the presence of trees which host nitrogen fixing bacteria. According to the insurance hypothesis [34], the maintenance of functional redundancy in ecological communities is important for ecosystem stability and resilience after a disturbance as more species performing similar functions will provide insurance to the system through compensatory growth.

In conclusion, our results support our hypothesis that selected plant traits would differ among the different fire frequency regimes. In particular, maximum height and species density were higher in LFF, while relative bark thickness was higher in high fire frequency regimes. In addition, although increase in fire frequency did not alter species diversity and richness, it did reduce functional richness and functional redundancy due to loss of functional traits. This study, therefore, demonstrated that functional diversity rather than taxonomic diversity only can better reflect ecosystem pattern and processes which has 
implications on wet savanna conservation especially in the face of frequent fires. The results also suggest that certain traits such as nitrogen fixation were partly lost in high fire frequency zones which can potentially reduce the resilience of the community. Although our conclusions are based on historical fire data which may be inaccurate, it provides valuable insight into the impact of fire on savanna ecosystem functioning. The study also contributes to the broader literature on the determinants of savanna ecosystems, in particular how they are shaped by fire regimes. We recommend that (i) NNP staff should continue to maintain a reliable and up-to-date fire database that serves as baseline for fire research and (ii) further research on the effect of other fire regimes (such as intensity) affect functional diversity in a long-term experiment.

\section{Data Availability}

The data used to support the findings of this study are available from the corresponding author upon request.

\section{Conflicts of Interest}

The authors declare no conflicts of interest regarding the use of research contents and publication of the paper.

\section{Acknowledgments}

The authors are grateful to the assistance of Zimbabwe Parks and Wildlife Management Authority and Nyanga National Park staff.

\section{References}

[1] S. Archibald, G. P. Hempson, and C. Lehmann, "A unified framework for plant life-history strategies shaped by fire and herbivory," New Phytologist, vol. 224, no. 4, pp. 1490-1503, 2019.

[2] F. Bello, J. Lepš, S. Lavorel, and M. Moretti, "Importance of species abundance for assessment of trait composition: an example based on pollinator communities," Community Ecology, vol. 8, no. 2, pp. 163-170, 2007.

[3] R. Ben-Shahar, "Changes in structure of savanna woodlands in northern Botswanafollowing the impacts of elephants and fire, following the impacts of elephants and fire," Plant Ecology, vol. 136, no. 2, p. 189, 1998.

[4] W. Bond and J. Keeley, "Fire as a global "herbivore": the ecology and evolution of flammable ecosystems," Trends in Ecology \& Evolution, vol. 20, no. 7, pp. 387-394, 2005.

[5] W. J. Bond and C. L. Parr, "Beyond the forest edge: ecology, diversity and conservation of the grassy biomes," Biological Conservation, vol. 143, no. 10, pp. 2395-2404, 2010.

[6] W. J. Bond, G. F. Midgley, and F. I. Woodward, "What controls South African vegetation-climate or fire?" South African Journal of Botany, vol. 69, no. 1, pp. 79-91, 2003.

[7] Z. Botta-Dukát, "Rao' s quadratic entropy as a measure of functional diversity based on multiple traits," Journal of Vegetation Science, vol. 16, pp. 533-540, 2005.

[8] R. Buitenwerf, W. J. Bond, N. Stevens, and W. S. W. Trollope, "Increased tree densities in South African savannas: $>50$ years of data suggests $\mathrm{CO} 2$ as a driver," Global Change Biology, vol. 18, no. 2, pp. 675-684, 2011.
[9] B. J. Cardinale, J. E. Duffy, A. Gonzalez et al., "Biodiversity loss and its impact on humanity," Nature, vol. 486, no. 7401, pp. 59-67.

[10] A. E. Perrings and U. Zieger, "A reassessment of the firetolerance of some miombo woody species in the Central Province, Zambia miombo woody species in the central province, miombo woody species in the central province," African Journal of Ecology, vol. 38, no. 2, pp. 138-146, 2000.

[11] T. Charles-Dominique, G. F. Midgley, and W. J. Bond, "Fire frequency filters species by bark traits in a savanna-forest mosaic," Journal of Vegetation Science, vol. 28, no. 4, pp. 728-735, 2017.

[12] K. Coates-Palgrave, Trees of Southern Africa, Struik, Cape Town, Africa, 1997.

[13] R. K. Colwell, Estimate S 9.1.0 User's guide. Available at: http://viceroy.eeb.uconn.edu/estimates (1 Accessed June, 2017], 2013.

[14] A. B. Davies, P. Eggleton, B. J. van Rensburg, and C. L. Parr, "The pyrodiversity-biodiversity hypothesis: a test with savanna termite assemblages," Journal of Applied Ecology, vol. 49, no. 2, pp. 422-430, 2012.

[15] Department of National Parks and Wildlife Management, Nyanga National Park Management Plan, Park Management Plan, Government printers, Nyanga, zimbabwe, 2008.

[16] A. P. Devine, I. Stott, R. A. McDonald, and I. M. D. Maclean, "Woody cover in wet and dry African savannas after six decades of experimental fires," Journal of Ecology, vol. 103, no. 2, pp. 473-478, 2015.

[17] S. D'́raz and M. Cabido, "Vive la différence: plant functional diversity matters to ecosystem processes," Trends in Ecology \& Evolution, vol. 16, pp. 646-655, 2001.

[18] T. Elmqvist, C. Folke, M. Nyström et al., "Response diversity, ecosystem change, and resilience," Frontiers in Ecology and the Environment, vol. 1, no. 9, pp. 488-494, 2003.

[19] V. Fernández-García, E. Marcos, P. Z. Fulé, O. Reyes, V. M. Santana, and L. Calvo, "Fire regimes shape diversity and traits of vegetation under different climatic conditions," Science of the Total Environment, vol. 716, p. 137, 2020.

[20] E. Gandiwa and P. Gandiwa, "Biodiversity conservation versus artisanal gold mining: a case study of Chimanimani National Park, Zimbabwe," Journal of Sustainable Development in Africa, vol. 14, pp. 29-37, 2012.

[21] E. Gandiwa and S. Kativu, "Influence of fire frequency on Colophospermum mopane and Combretum apiculatum woodland structure and composition in northern Gonarezhou National Park, Zimbabwe," Koedoe, vol. 51, no. 1, 2009.

[22] D. H. Hammond, J. M. Varner, J. S. Kush, and Z. Fan, "Contrasting sapling bark allocation of five southeastern USA hardwood tree species in a fire prone ecosystem," Ecosphere, vol. 6, pp. 1-13, 2015.

[23] S. I. Higgins, W. J. Bond, H. Combrink et al., "Which traits determine shifts in the abundance of tree species in a fireprone savanna?" Journal of Ecology, vol. 100, no. 6, pp. 1400-1410, 2012.

[24] S. I. Higgins, W. J. Bond, E. C. February et al., "Effects of four decades of fire manipulation on woody vegetation structure in savanna," Ecology, vol. 88, no. 5, pp. 1119-1125, 2007.

[25] S. I. Higgins, W. J. Bond, and W. S. W. Trollope, "Fire, resprouting and variability: a recipe for grass-tree coexistence in savanna recipe for grass-tree coexistence in savanna," Journal of Ecology, vol. 88, no. 2, pp. 213-229, 2000.

[26] J. E. Keeley, J. G. Pausas, P. W. Rundel, W. J. Bond, and R. A. Bradstock, "Fire as an evolutionary pressure shaping 
plant traits an evolutionary pressure shaping plant traits," Trends in Plant Science, vol. 16, no. 8, pp. 406-411, 2011.

[27] K. R. Kidd and J. M. Varner, "Differential relative bark thickness and aboveground growth discriminates fire resistance among hardwood sprouts in the southern Cascades, California," Trees, vol. 33, no. 1, pp. 267-277, 2019.

[28] C. J. Krebs, Ecology: The Experimental Analysis of Distribution and Abundance, Ecology. Harper and Row, New York, NY, USA, 2009.

[29] E. Laliberté and P. Legendre, "A distance-based framework for measuring functional diversity from multiple traits," Ecology, vol. 91, no. 1, pp. 299-305, 2010.

[30] M. J. Lawes, H. Adie, J. Russell-Smith, B. Murphy, and J. J. Midgley, "How do small savanna trees avoid stem mortality by fire? The roles of stem diameter, height and bark thickness," Ecosphere, vol. 2, pp. 1-13, 2011.

[31] M. J. Lawes, A. Richards, J. Dathe, and J. J. Midgley, "Bark thickness determines fire resistance of selected tree species from fire-prone tropical savanna in north Australia," Plant Ecology, vol. 212, no. 12, pp. 2057-2069, 2011.

[32] R. M. Lawton, "A study of the dynamic ecology of Zambian vegetation," The Journal of Ecology, vol. 66, no. 1, pp. 175-198, 1978.

[33] J. Leps, J. Osbornová-Kosinová, and M. Reimánek, “Community stability, complexity and species life history strategies," Vegetatio, vol. 50, pp. 53-63, 1982.

[34] M. Loreau, "Biodiversity and ecosystem functioning: a mechanistic model," Proceedings of the National Academy of Sciences, vol. 95, no. 10, pp. 5632-5636, 1998.

[35] N. W. H. Mason, F. de Bello, D. Mouillot, S. Pavoine, and S. Dray, "A guide for using functional diversity indices to reveal changes in assembly processes along ecological gradients," Journal of Vegetation Science, vol. 24, no. 5, pp. 794-806, 2013.

[36] N. W. Mason, H. Mouillot, W. G. Lee, and J. B. Wilson, "Functional richness, functional evenness and functional divergence: the primary components of functional diversity," Oikos, vol. 111, no. 1, pp. 112-118, 2005.

[37] S. T. Michaletz, E. A. Johnson, and M. T. Tyree, "Moving beyond the cambium necrosis hypothesis of post-fire tree mortality: cavitation and deformation of xylem in forest fires," New Phytologist, vol. 194, no. 1, pp. 254-263, 2012.

[38] D. A. Morrison, "Effects of fire intensity on plant species composition of sandstone communities in the Sydney region," Austral Ecology, vol. 27, no. 4, pp. 433-441, 2002.

[39] M. A. Mouchet, S. Villéger, N. W. H. Mason, and D. Mouillot, "Functional diversity measures: an overview of their redundancy and their ability to discriminate community assembly rules," Functional Ecology, vol. 24, no. 4, pp. 867-876, 2010.

[40] D. Mouillot, N. A. J. Graham, S. Villéger, N. W. H. Mason, and D. R. Bellwood, "A functional approach reveals community responses to disturbances," Trends in Ecology \& Evolution, vol. 28, no. 3, pp. 167-177, 2013.

[41] E. Mudongo, R. Fynn, and M. C. Bonyongo, "Influence of fire on woody vegetation density, cover and structure at Tiisa Kalahari Ranch in western Botswana," Grassland Science, vol. 62, no. 1, pp. 3-11, 2016.

[42] S. Naeem, "Species redundancy and ecosystem reliability," Conservation Biology, vol. 12, no. 1, pp. 39-45, 1998.

[43] L. L. Nefabas and J. Gambiza, "Fire-tolerance mechanisms of common woody plant species in a semiarid savanna in southwestern Zimbabwe," African Journal of Ecology, vol. 45, no. 4, pp. 550-556, 2007.
[44] C. C. Nóbrega, P. M. Brando, D. V. Silvério, L. Maracahipes, and P. de Marco Jr, "Effects of experimental fires on the phylogenetic and functional diversity of woody species in a neotropical forest," Forest Ecology and Management, vol. 450, pp. 117-497, 2019.

[45] T. P. Nyazika, P. Zisadza-Gandiwa, A. Chanyandura, N. Muboko, and E. Gandiwa, "Influence of fire frequency on woody vegetation structure and composition in Lake Chivero Recreational Park, northern Zimbabwe," Tropical Ecology, vol. 58, pp. 583-589, 2017.

[46] N. Pérez-Harguindeguy, S. Díaz, E. Garnier, E. Garnier et al., "New handbook for standardised measurement of plant functional traits worldwide," Australian Journal of Botany, vol. 61, no. 3, pp. 167-234, 2013.

[47] O. L. Petchey and K. J. Gaston, "Functional diversity: back to basics and looking forward," Ecology Letters, vol. 9, no. 6, pp. 741-758, 2006.

[48] J. Pinheiro, D. Bates, S. DebRoy, D. Sarkar, and R. Core Team, Nlme: Linear and Nonlinear Mixed Effects Models, R package version 3.1-139, https://CRAN.R-project.org/package=nlme, 2019.

[49] J. Podani, "Extending Gower's general coefficient of similarity to ordinal characters," Taxon, vol. 48, no. 2, pp. 331-340, 1999.

[50] E. C. Pryde, D. G. Nimmo, G. J. Holland, and S. J. Watson, "Species' traits affect the occurrence of birds in a native timber plantation landscape," Animal Conservation, vol. 19, no. 6, pp. 526-538, 2016.

[51] R Core Team, R: A Language and Environment for Statistical Computing, R Foundation for Statistical Computing, Vienna, Austria, URL https://www.R-project.org/, 2018.

[52] C. M. Ryan and M. Williams, "How does fire intensity and frequency affect miombo woodland tree populations and biomass?" Ecological Applications, vol. 21, no. 1, pp. 48-60, 2011.

[53] M. Sankaran, "Determinants of woody cover in African savannas," Nature, vol. 438, no. 7069, pp. 846-849, 2005.

[54] M. Sankaran, J. Ratnam, and N. P. Hanan, "Tree-grass coexistence in savannas revisited - insights from an examination of assumptions and mechanisms invoked in existing models," Ecology Letters, vol. 7, no. 6, pp. 480-490, 2004.

[55] R. J. Scholes and S. R. Archer, "Tree-grass interactions in savannas," Annual Review of Ecology and Systematics, vol. 28, no. 1, pp. 517-544, 1997.

[56] J. Singh, S. R. Levick, M. Guderle, C. Schmullius, and S. E. Trumbore, "Variability in fire-induced change to vegetation physiognomy and biomass in semi-arid savanna," Ecosphere, vol. 9, Article ID e02514, 2018.

[57] I. P. J. Smit, G. P. Asner, N. Govender, T. Kennedy-Bowdoin, D. E. Knapp, and J. Jacobson, "Effects of fire on woody vegetation structure in African savanna," Ecological Applications, vol. 20, no. 7, pp. 1865-1875, 2010.

[58] A. C. Staver, P. M. Brando, J. Barlow et al., "Thinner bark increases sensitivity of wetter Amazonian tropical forests to fire," Ecology Letters, vol. 23, no. 1, pp. 99-106, 2019.

[59] C. J. F. Ter Braak and P. Šmilauer, "CANOCO reference manual and CanoDraw for Windows user's guide: software for community ordination, version 4.5," Microcomputer Power, Ithaca, NY, USA, 2002.

[60] S. Villéger, N. W. H. Mason, and D. Mouillot, "New multidimensional functional diversity indices for a multifaceted framework in functional ecology," Ecology, vol. 89, no. 8, pp. 2290-2301, 2008. 
[61] J. L. Wakeling, A. C. Staver, and W. J. Bond, "Simply the best: the transition of savanna saplings to trees," Oikos, vol. 120, no. 10, pp. 1448-1451, 2011.

[62] B. H. Walker, "An approach to the monitoring of changes in the composition and utilisation of woodland and savanna vegetation," South African Journal of Wildlife Resources, vol. 6, pp. 1-32, 1976.

[63] H. Wickham, ggplot2: Elegant Graphics for Data Analysis, Springer-Verlag, New York, NY, USA, 2016.

[64] P. Zisadza-Gandiwa, E. Gandiwa, T. B. Matokwe et al., "Preliminary assessment of vegetation fires and their impact in Nyanga national park, Zimbabwe," Greener Journal of Biological Sciences, vol. 4, pp. 009-017, 2014. 